\title{
Ultrasonography, Histopathological, Udder Alterations and Bacteriological Investigations for Diagnosis of Mastitic Goats
}

\author{
Ebtsam E.Z. Kotb ${ }^{* 1}$, Fadel, M. ${ }^{2}$, Ola A. Abd El-Fattah ${ }^{5}$, Azab, A.M.S. ${ }^{3}$ Amal Z.A. Leil ${ }^{4}$ \\ ${ }^{1}$ Udder Health and Neonatal Diseases Department, Agricultural Research Center (ARC), Egypt. \\ ${ }^{2}$ Diagnostic and Sonography Department, Agricultural Research Center (ARC), Egypt. \\ ${ }^{3}$ Dept. of Reproductive Pathology, Agricultural Research Center (ARC), Egypt. \\ ${ }^{4}$ Field investigation Department, Animal Reproduction Research Institute, Agricultural Research Center, Egypt. \\ ${ }^{5}$ Giza Lab. Animal Health Research Institute, Agricultural Research Center (ARC), Egypt. \\ *Corresponding Author, Ebtsam E.Z. Kotb, E-Mail: dekotb@yahoo.com
}

\begin{abstract}
The purpose of this study was to evaluate the ultrasound and histopathological findings in comparison with the bacteriological examination to help in prognosis decision for udder alteration occurred by different cause and forms of mastitis. 40 Egyptian Baladi female goats (does) were examined for detection of mastitis during lactation period by clinical and laboratory examination include inspection, CMT, ultrasonography, pathological and bacteriology examination accompanied with antimicrobial susceptibility for isolated microorganisms (M.O.) for detection of udder alterations due to mastitis The results revealed the prevalence of subclinical and clinical mastitis was $25 \%$ and $12.5 \%$ respectively. $30 \%$ of the isolates were coagulase-negative Staph. (CNS), while S. aureus and Strep. Spp. were $25 \%$ for each and E.coli represent $10 \%$ in subclinical milk samples, although these M.O. represented $40 \%, 30 \%, 10 \%$ and $0 \%$ respectively in clinical milk samples. Ultrasonography of the parenchyma of healthy mammary gland appeared as a homogenous structure of average echogenicity filled with anechogenic content (milk). In contrast, the characteristic changes that occurred during all different mastitis phases in the mammary glandular parenchyma, teat and the milk appeared with different echogenicity. Histopathological features of tissue samples obtained by surgical biopsy technique described some different characteristic features of chronic, diffused interstitial mastitis lesions compatible with a longstanding subclinical infection. All forms of mastitis require microbiological confirmation for definitive diagnosis. Ultrasonography and histopathology give a clear prognosis for the status of the udder to minimize the impact of it.
\end{abstract}

Original Article:

DOI: HTTPS://DX.DOI.ORG/10.2 $\underline{\text { 1608/JAVS.2020.85593 }}$

Received: 17 March, 2020.

Accepted : 18 April, 2020.

Published in April, 2020.

This is an open access article under the term of the Creative Commons Attribution $\quad 4.0 \quad$ (CC-BY) International License . To view a copy of this license, visit http://creativecommons.org/licenses/ by/4.0/

Keywords: goat's udder, histopathology, mastitis, microbiology, J. Appl. Vet. Sci., 5(2 ): 77 - 86. ultrasonography.

\section{INTRODUCTION}

There is an increasing awareness in many countries for using the goat as a valid animal for milk production. Recently, in Egypt, the goat became a source of meat, milk and hide (Adam et al., 2017). Does' milk is superior in quality compared with milk of other species, as its milk is characterized by high nutritional properties like it is rich in minerals, proteins and vitamin A, with smaller fat globules, facilitate the digestion process, with lower lactose content which can be consumed by lactose-intolerant people or have allergies to the milk of other species (Nogueira Filho et al., 2010). Otherwise, mastitis hinders milk production and its quality, caused by the interaction of several factors including animals, the surrounding environment and microorganisms. Where infection of the udder usually takes place directly through teat canal (Abu et al., 2013). Thus several M.O. can affect both mammary epithelial cell and alveolar function followed by impairment the quality and quantity of milk initiating serious hazard for public health (Jai et al., 2005 and Addis et al.,2019). 


\section{Ultrasonography, Histopathological, Udder Alterations .......}

Mastitis plays an active role in changes in parenchymal tissue. It releases harmful substances producing lesions varying from increased milk leukocytes infiltration with no gross changes in milk to increase vascular permeability with hyperemia which may develop fibrosis or severe toxaemia, finally leading to milk losses Ahmed et al., (2020).

Thus, alterations necessitate fast and accurate diagnostic techniques as ultrasonography which is a non-invasive and perfect technique used for determination of several physiological and pathological udder disorders of the ruminants (Szencziova and Strapak,2012; Ebtsam et al., 2014a). The imaging technique depends on the intensity of the sound reflection amongst the closely related structures, the terms hyper-echoic (high intensity), hypo-echoic (low intensity) and anechoic (no intensity) are an expression for ultrasonographic characterization of these morphological structures of the mammary gland and histopathological examinations which clarify the changes specific for subclinical, acute and chronic inflammation (Hussain et al., 2012).

The negative economic impact due to mastitis is high in small ruminants' herds. Loss of milk production associate with low quality, increase veterinary and labour fees which are important points relate to this disease (Ebtsam et al., 2014b). Inspection and palpation, California Mastitis Test (CMT) and milk composition are useful indicators depending upon the severity of inflammatory response to infection while the bacteriological examination is considered the main accurate tool for diagnosis of intra-mammary infection (IMI) (Ebtsam 2008; NMC, 2011). There is little information about mammary gland biopsy in goats. Despite its reduced use for the diagnosis of mammary disorders, this procedure may be a tool to study the cellular proliferation and differentiation that occur during lactogenesis and help elucidate these processes. As examples, tissue samples obtain by surgical biopsy technique have been used for histological, histochemical, and ultrastructural studies of lactating mammary glands in goats (El-Sayed et al., 2009,2013 and Sousa et al., 2017).

The present research was focused on getting the benefits of ultrasonography combined with histopathological finding in comparison with bacteriological examination for detection and monitoring of udder alterations prognosis that support the decision of treatment or culling and replacement in farms.

\section{MATERIALS AND METHODS}

\section{Field evaluation for animals}

Egyptian Baladi female goats (does) with a brief history of animal husbandry practices were examined for mastitis during the lactation period ( $n=40$, age $2-5$ years, weight $18-27 \mathrm{kgs}$ ) by:

1. Clinical examination: Included inspection and palpation for detection of cardinal signs of inflammation (redness, hotness, pain and swelling) and abnormal findings were recorded. Also, the gross examination included the position, form and shape of the udder.

2. California Mastitis Test (CMT): According to Ebtsam (2001) and Quinn et al., (2002); It was conducted on 35 apparently healthy does as a screening test for diagnosis of subclinical mastitis. Collected milk samples were strictly standardized after stripping about $2 \mathrm{ml}$ of milk then inspected for evaluation.

3. Ultrasonographic examination: It was carried out on 15 does (5 suffering from clinical mastitis and ten from subclinical mastitis by using ultrasound equipment MyLabTM30 VET (Esaote S.P.A., Genova, Liguria Italy) with a micro convex multifrequency $(3.5-8.5 \mathrm{MHz})$ probe, using the direct contact method. For better contact between the transducer and udder skin ultrasonography gel(Jaay Vee Meditech International, Pondicherry, India) was applied after a thorough cleaning of the udder and teat (Ebtsam $\boldsymbol{e t}$ al., 2014a; Fasulkov $\boldsymbol{e} t$ al., 2014).

\section{Laboratory Examination}

1.Bacteriological Examination: It was done according to National Mastitis Council (NMC) (2011): 30 milk samples (10 from clinical and 20 from CMT positive udder halves) were collected in sterile vials for bacteriological analysis under aseptic conditions. The samples were transported to the Udder Health and Neonate's Department Laboratory in Animal Reproduction Research Institute (ARRI) in Egypt at $4^{\circ} \mathrm{C}$ then the milk samples were plated onto different specific media (Oxoid, UK) and incubated aerobically at $37^{\circ} \mathrm{C} /$ for 24- 48 hrs. Suspected colonies were subcultured for further biochemical identifications.

2. Antimicrobial susceptibility tests: As published by Clinical and Laboratory Standards Institute (2014). The antibiotics disks used were brought from Oxoid (UK), penicillin G (P, $10 \mathrm{IU})$, gentamicin $(\mathrm{CN}, 10 \mu \mathrm{g})$ and tetracycline (TE, 30 $\mu \mathrm{g})$, amoxicillin + clavulanic acid (AMC, 30), norfloxacin (NOR,10 $\mu \mathrm{g})$ neomycin $(\mathrm{N}, 30 \mu \mathrm{g})$, cephradine $(\mathrm{CE}, 30 \mu \mathrm{g})$ and cefquinome (CEQ 30 $\mu \mathrm{g})$.

3.Pathological Examination: Incision of the mammary gland and lymph nodes biopsies were taken after aseptic preparation using $5 \mathrm{ml}$ Novocain $1 \%$ infiltrated along with the incision cut then a cubic specimen of approximately $1 \mathrm{~g}$ weight was incised with a scalpel. After that, cut surfaces were closed by suturing and followed by antibiotic 


\section{Ebtsam E.Z. Kotb et al.}

application as described by Fasulkov $\boldsymbol{e t}$ al., ( 2015) and Sousa et al., ( 2017).

All tissue specimens were immersed and fixed in formol saline solution ( $10 \%$ formalin in $0.9 \% \mathrm{NaCl})$ then routinely processed in an automated tissue processor (dehydrated in grades of ethyl alcohol and cleared in xylene), embedded in paraffin, sectioned at 3-5 $\mu \mathrm{m}$ and stained with haematoxylin and eosin stain Bancroft and Gamble(2018), then examined by light microscopy.

\section{RESULTS}

\section{Field clinical investigations and CMT results}

These examinations revealed that 15 does, 5 of them exhibited clinical inflammation (hot, tenderness, swollen with abnormal colour and consistency of milk) as seen in Fig (1). In contrast, the other ten does have no inflammatory signs which suffer from subclinical mastitis with positive CMT reactions, as shown in Table (1).

\begin{tabular}{|ccc|}
\hline Examined animals & No. & $\%$ \\
\hline Clinical animals & $5 / 40$ & 12.5 \\
\hline $\begin{array}{c}\text { Sub-clinical } \\
\text { animals }\end{array}$ & $10 / 40$ & 25 \\
\hline
\end{tabular}

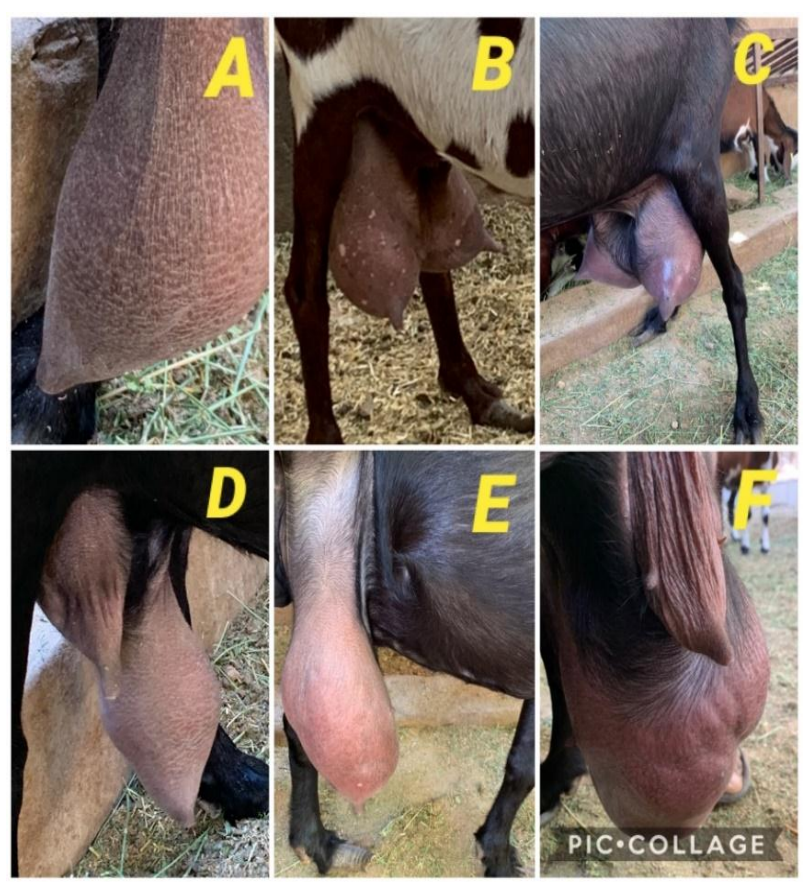

Fig. 1: Examined udder, (A) healthy udder, (D) subclinical (B, C, E \& F) different clinical forms of mastitc udders

\section{Bacteriological examination}

Milk samples revealed 26 isolates where 18/20 $(90 \%)$ and $8 / 10(80 \%)$ from sub-clinical and clinical samples and the reminders $2 / 20(10 \%)$ and 2/10 (20\%) were negative for bacterial isolation respectively. Coagulase-Negative Staph. (CNS) were commonly isolated with prevalence $30 \%$, S. aureus and Strep. Spp. were 25\% for each, while, E.coli represented 10\% of the isolates in sub-clinical samples CoagulaseNegative Staph. (CNS) S. aureus, Strep. Spp. and E.coli represented 40\%, 30\%, 10\% and $0 \%$ respectively in clinical samples as shown in Table (2).

Table 2: Prevalence of bacterial isolates from milk samples

\begin{tabular}{|c|c|c|c|c|c|c|c|c|c|c|}
\hline \multirow[t]{2}{*}{ ?.3 } & \multicolumn{2}{|c|}{ f } & \multicolumn{2}{|c|}{ 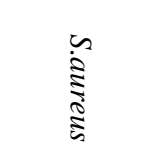 } & \multicolumn{2}{|c|}{ 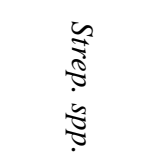 } & \multicolumn{2}{|c|}{$\begin{array}{l}\text { } \\
\vdots \\
\vdots\end{array}$} & \multicolumn{2}{|c|}{ 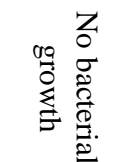 } \\
\hline & No & $\%$ & No & $\%$ & No & $\%$ & No & $\%$ & No & $\%$ \\
\hline  & 4 & 40 & 3 & 30 & 1 & 10 & 0 & 0 & 2 & 20 \\
\hline 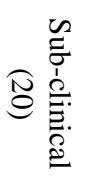 & 6 & 30 & 5 & 25 & 5 & 25 & 2 & 10 & 2 & 10 \\
\hline
\end{tabular}

CNS: Coagulase-Negative Staph

\section{Antimicrobial susceptibility tests of isolated bacteria}

Most bacteria in the current study were sensitive to Cefquinome, Amoxicillin + clavulanic acid, Norfloxacin, gentamycin and Cephradine, at the contrast increasing bacterial resistant pattern to penicillin $\mathrm{G}$ and Tetracycline recorded in the Table (3). 
Ultrasonography, Histopathological, Udder Alterations ......

Table 3: Antimicrobial susceptibility tests of isolated bacteria

\begin{tabular}{|c|c|c|c|}
\hline $\begin{array}{c}\text { The } \\
\text { sensitivity } \\
\text { of M.O to } \\
\text { antibiotics }\end{array}$ & High sensitivity & Moderate sensitivity & Resistance sensitivity \\
\hline CNS & $\begin{array}{l}\text { Cefquinome, Amoxicillin + Clavulanic Acid, } \\
\text { Norfloxacin, Gentamycin and Cephradine }\end{array}$ & Neomycin, & $\begin{array}{l}\text { Tetracycline, and } \\
\text { Penicillin G }\end{array}$ \\
\hline S.aureus & $\begin{array}{c}\text { Cefquinome, Amoxicillin +Clavulanic Acid } \\
\text { and Norfloxacin }\end{array}$ & $\begin{array}{l}\text { Gentamycin, } \\
\text { Neomycin and } \\
\text { Cephradine }\end{array}$ & $\begin{array}{l}\text { Tetracycline, and } \\
\text { Penicillin G }\end{array}$ \\
\hline Strep. Spp. & $\begin{array}{c}\text { Cefquinome, Amoxicillin + Clavulanic Acid, } \\
\text { Norfloxacin, Gentamycin, Neomycin and } \\
\text { Cephradine }\end{array}$ & $\begin{array}{l}\text { Tetracycline and } \\
\text { Penicillin G }\end{array}$ & - \\
\hline E.coli & $\begin{array}{c}\text { Tetracycline, Cefquinome, Amoxicillin }+ \\
\text { Clavulanic Acid, Norfloxacin, Gentamycin, } \\
\text { Cephradine and Neomycin }\end{array}$ & - & Penicillin G \\
\hline
\end{tabular}

\section{Ultrasonographic examination results}

The results of the current study showed that visualization of normal udder where the skin appeared as a hyper-echoic line, while the parenchyma of a healthy mammary gland as appeared a homogenous structure of average echogenicity filled with anechoic content (milk) and presence of anechoic lactiferous ducts (Fig. 2). Also, it was observed that the mammary gland in goats suffering from subclinical mastitis revealed a non-homogenous and hypo- to hyperechoic mammary gland parenchyma structure, with a lack of clear visualization of the teat canals (Fig. 3). However, ultrasonography recorded in the animals exhibited udder atrophy and fibrosis in chronic mastitis, displayed thick, hyperechoic teat wall, as well as numerous hyperechoic structures in the teat cistern and udder parenchyma, showed whole replacement of the milk alveoli with hyperechoic fibrous tissue (Fig. 4). In another case, an abscess was found within the mammary parenchyma which appeared as a visible round distinguished structure, surrounded by a hyperechoic capsule filled with hypoechoic and hyperechogenic secretion (calcified pus). Also, diagnostic teat wall thickness was detected with a narrow teat canal and fibrous changes in mammary gland parenchyma appeared as hyperechoic (Fig. 5).
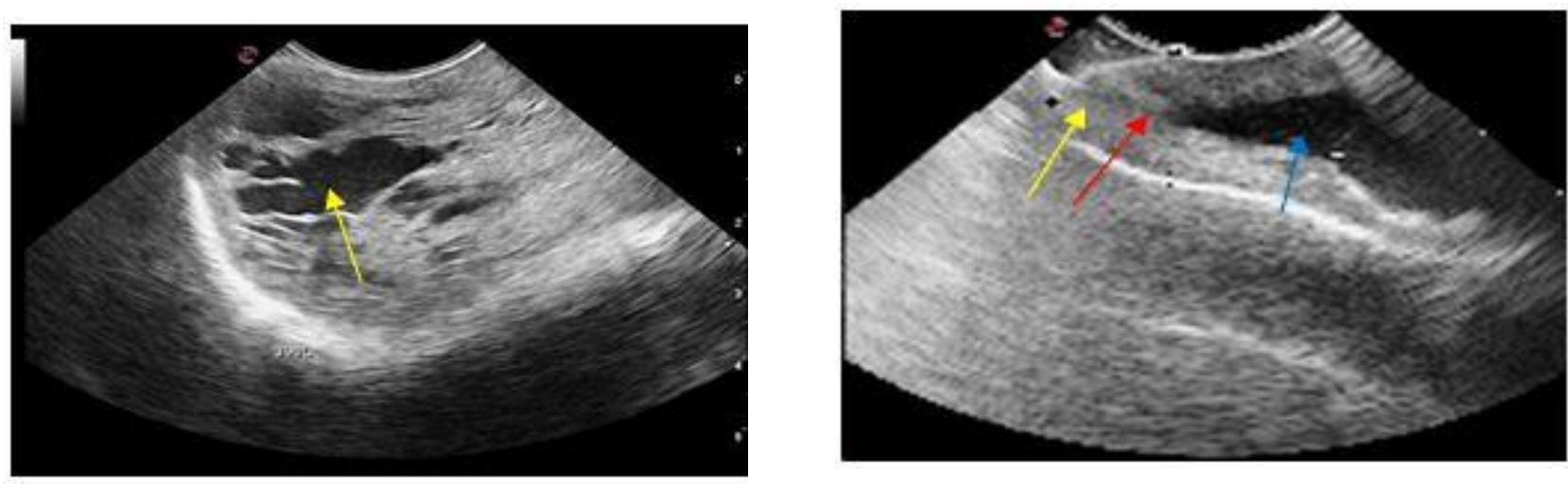

Fig 2: Ultrasound image of the lactating goat. The left picture showed the presence of anechoic content (milk) in the cistern region of mammary parenchyma, while right picture showed Teat wall; Teat orifice(yellow arrow); Teat canal (red arrow); Transition area between the teat sinus and teat canal (rosette of Furstenberg) and Teat sinus (blue arrow) ( healthy udder. 


\section{Ebtsam E.Z. Kotb et al.}
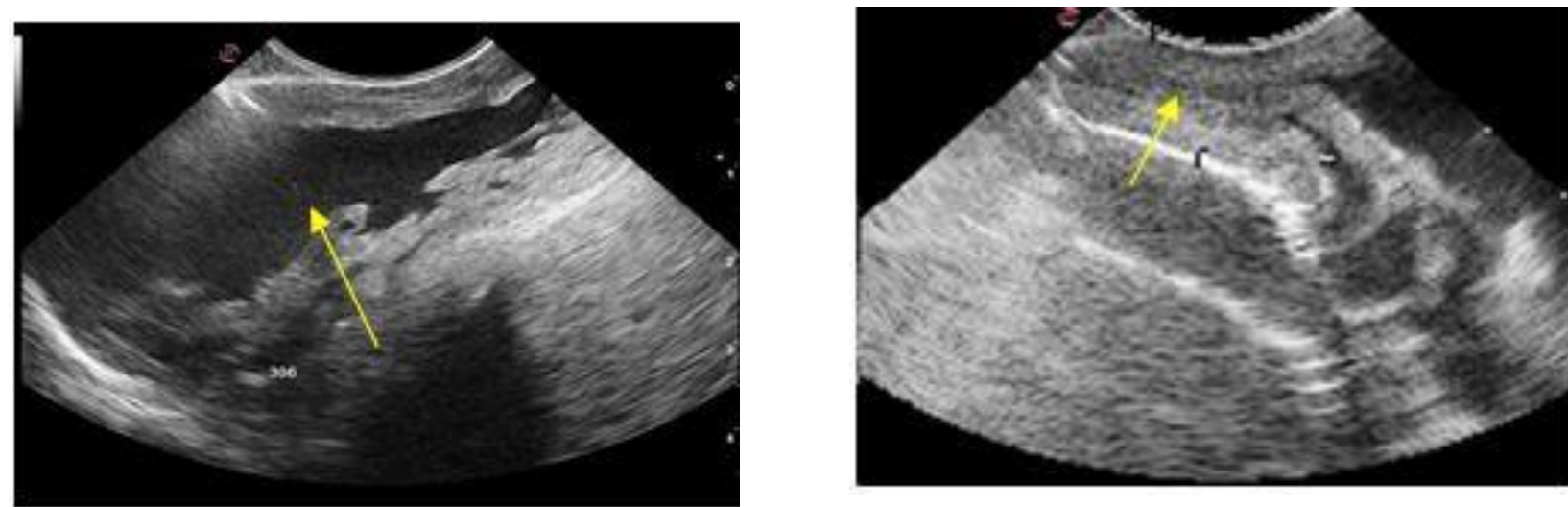

Fig 3: Ultrasound image of subclinical mastitc udder, left picture showed a large amount of turbid echoic content (milk) in the cistern, while right picture showed the teat wall thickness and teat canal with normal thickness.
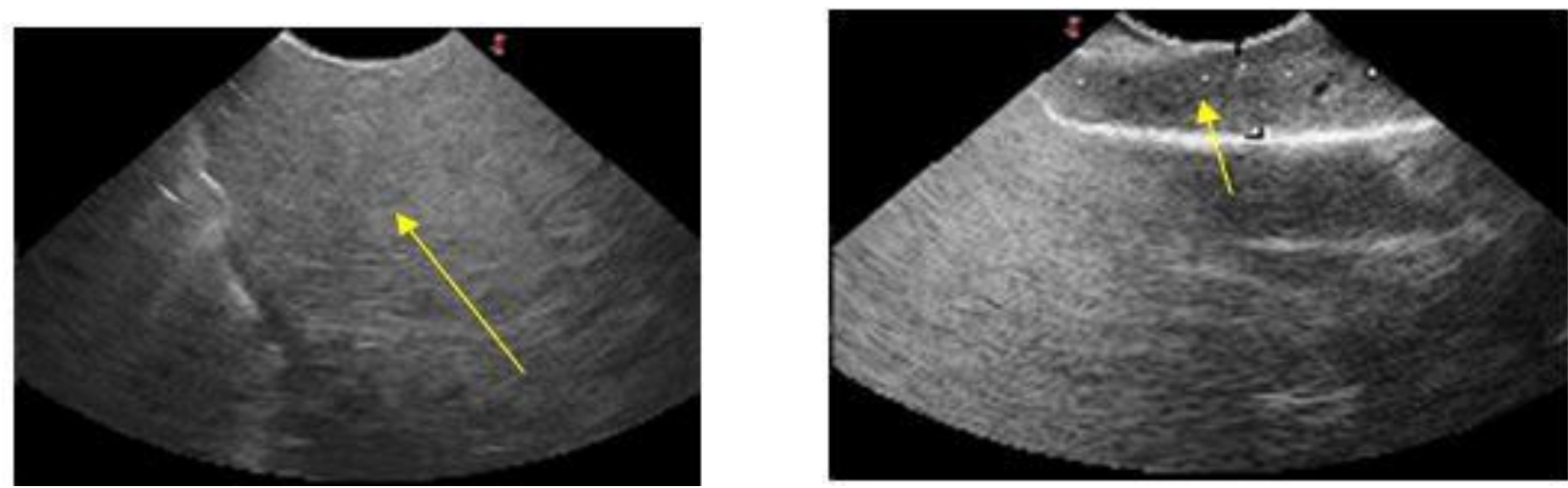

Fig 4: Ultrasound image of chronic sever fibrosed udder tissue, in the left picture, showed hyperechoic tissue without acini or milk in the cistern, while right picture showed a hyperechoic thickness of teat canal.
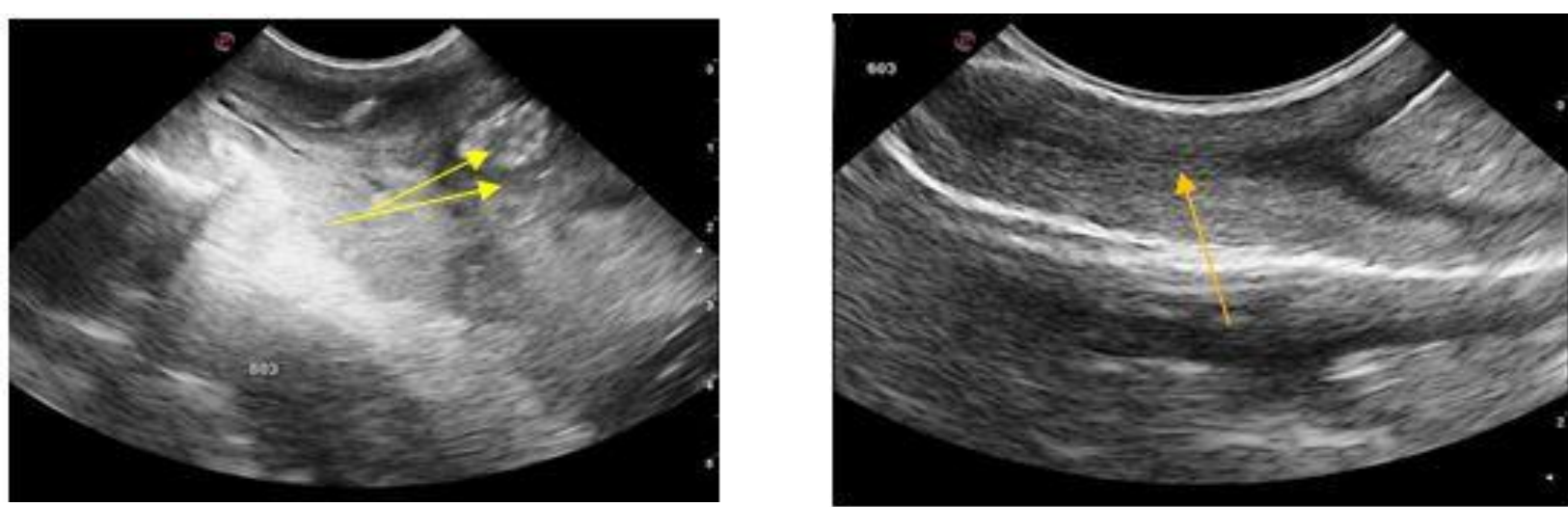

Fig 5: Ultrasound image of udder parenchyma in the left picture showed hypoechoic visible capsule containing hypoechoic and hyperechoic secretion (Abscess with calcified pus), while right picture showing hyperechoic teat wall thickness with a anarrow lumen.

\section{Histopathological examination}

Histopathological evaluation of the mammary gland varies from subclinical to severe chronic mastitis or fibrosis. Subclinical mammary tissue usually showed pictures with mild vacuolar degeneration of acinar epithelial cells and narrowing of lactiferous ducts (Fig. 6). 


\section{Ultrasonography, Histopathological, Udder Alterations ......}

Mammary gland tissues of mastitic cases revealed focal and/or diffuse subclinical to chronic lymphocytic mastitis in which there was a proliferation of intralobular and interlobular fibrous connective tissue accompanied with obvious infiltrations of lymphocytes, macrophages and plasma cells (Fig. 7 and 10). Atrophy and destruction of alveoli observed, as well as alveolar epithelium, appeared flattened (Fig. 7 and 8). While other cases showed epithelial vacuolations with cystic dilatation of acini. The damaged alveoli were empty or contained mononuclear inflammatory cells and few neutrophils together with desquamated epithelium and fibrin network (Fig. 9 and 10). Corpora amylacea detected inside acini (Fig. 7 and 9). The increase of the interstitial tissue was of variable intensity. Moderate hyperplasia of the epithelial lining of lactiferous ducts was detected and associated with subepithelial mononuclear cells aggregations as well as lymphocytic exocytosis. Interlobular connective tissue was mild to expand by oedema moderately. Blood vessels showed thickening of their tunica media with vasculitis (Fig. 10).

In teats, hyperplasia of covering epithelium (hyperplastic down growth of basal layer with excessive melanosis) was noticed with marked increasing of keratin layer (fragmentation and scaly appearance in some areas). Focal mononuclear inflammatory cell infiltrations, mainly lymphocytes, were seen. Extensive vascular thickening with narrowing of the lumen of blood vessels with vasculitis was noticed. Also, some hair follicles were destructed, and hair shafts were fragmented (Fig. 11 and 12).

The mammary lymph nodes displayed a slight to moderate follicular hyperplasia with germinal centres and extravasated blood into cortical and medullary regions. In addition, in some does, lymph depletion was found (Fig. 13).

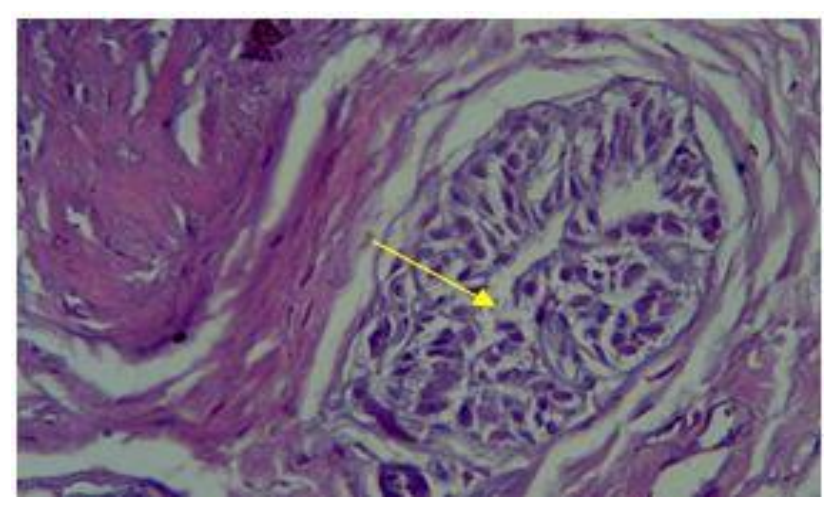

Fig. 6: Goat mammary gland showing mild vacuolar degeneration of acinar epithelium (inactive mammary gland) (H\&E, X400).



Fig. 8: Goat mammary gland with chronic mastitis showing vacuolar degeneration, destruction and desquamation of acinar epithelium with a focal aggregation of mononuclear inflammatory cells (blue arrow) as well as hyperemia of blood capillaries (yellow arrow) (H\&E, X400

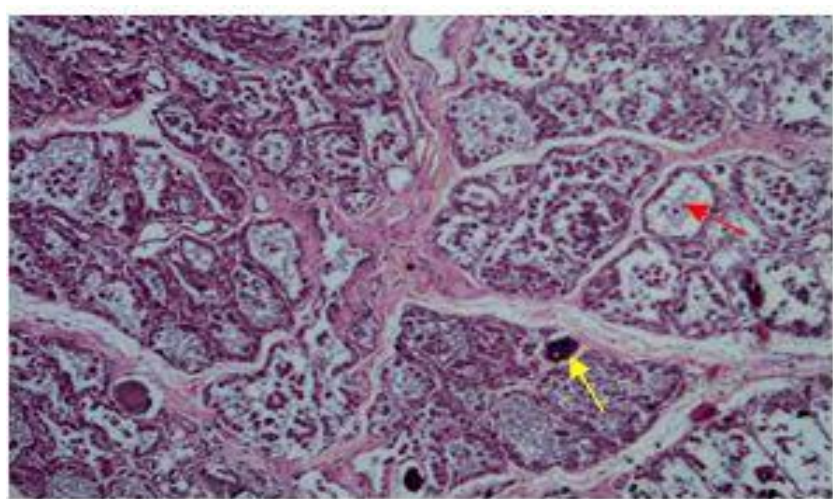

Fig. 7: Goat mammary gland with chronic mastitis showing vacuolar degeneration, destruction and desquamation of acinar epithelium (red arrow). Interstitial fibrosis and corpora amylacea were present(yellow arrow) (H\&E, X100).

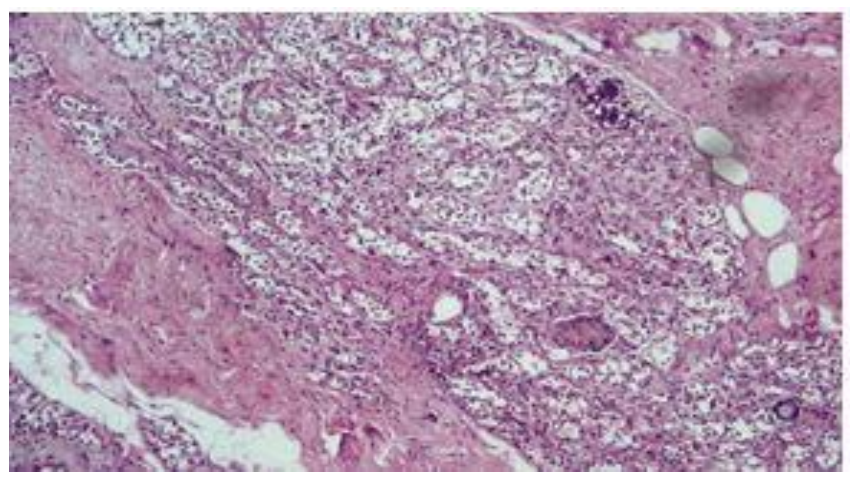

Fig. 9: Goat mammary gland with subacute mastitis showing destructed acinar epithelium. Mild interstitial fibrosis was present with a focal aggregation of inflammatory cells and corpora amylacea (H\&E, $\mathrm{X} 100)$. 




Fig. 10: Goat mammary gland with subacute mastitis showing vacuolar degeneration, destruction and desquamation of acinar epithelium (red arrow) with a focal aggregation of mononuclear inflammatory cells (mainly lymphocytes and few plasma cells) as well as mild interstitial fibrosis (H\&E, X400).

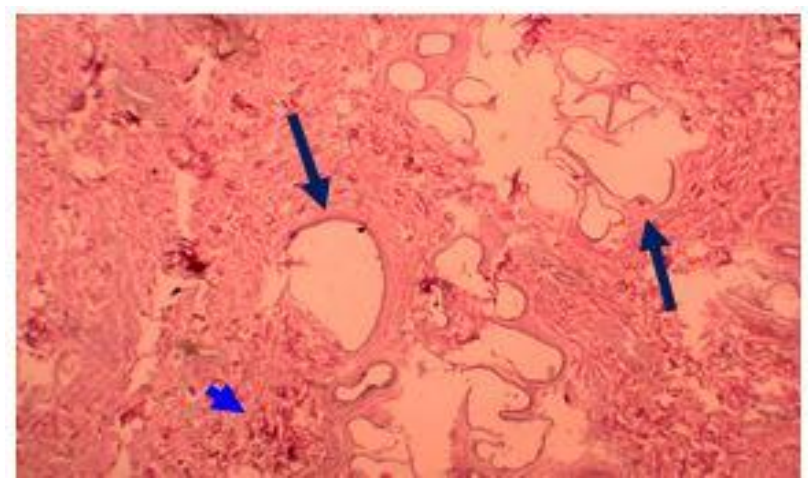

Fig. 12: Goat teat showing hyperkeratosis and cystic dilatation of lactiferous ducts (arrows). Focal mononuclear inflammatory cell infiltrations (arrowhead) mainly lymphocytes were seen $(\mathrm{H} \& \mathrm{E}, \mathrm{X} 40)$.

\section{DISCUSSION}

Mastitis is a multifactor disorder, which increases risks of culling of animals and requires an understanding of the exact mechanism of its pathogenesis (Ebtsam and Jehan, 2020). Even though significant technological advances have been made, mastitis continues to be a major economic issue for dairy producers, necessitating researchers and dairy advisors continue to refine the recommended mastitis control program (Shaheen et al.., 2016).

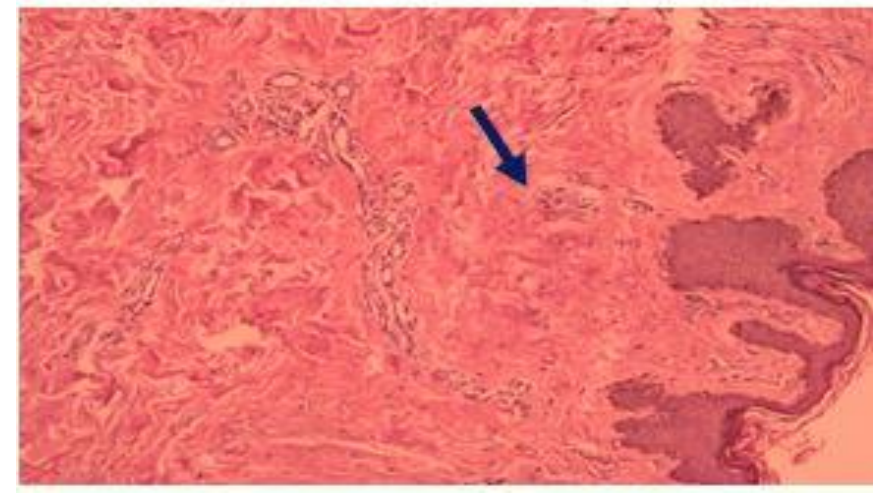

Fig. 11: Goat teat showing hyperplastic down growth of basal layer with melanosis and hyperkeratosis were present. Destructed hair follicle with fragmented hair shafts was seen (arrow). Focal mononuclear inflammatory cell infiltrations were seen $(\mathrm{H} \& \mathrm{E}$, $\mathrm{X} 100)$.

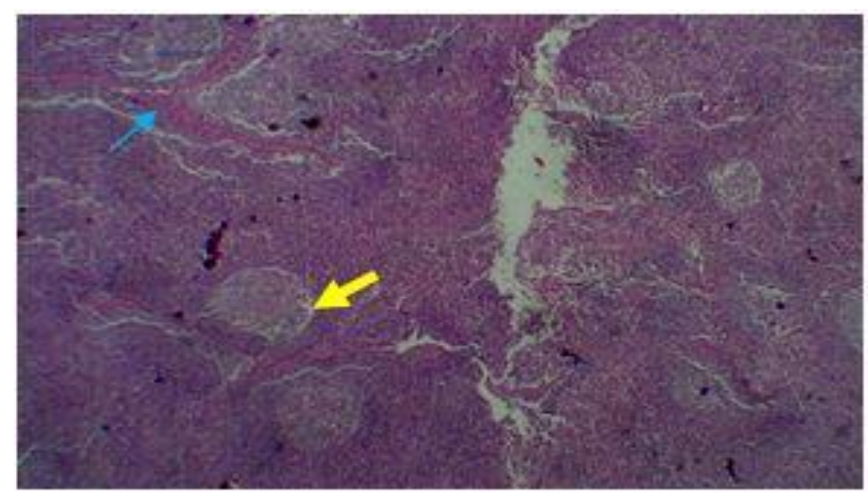

Fig. 13: Goat supramammary lymph node affected with chronic mastitis showing lymphoid depletion with the destruction of some lymphoid follicles (yellow arrow )and extravasated blood (blue arrow) into cortical and medullary regions (H\&E, X40).

In the present study, clinical investigation and CMT yielded the prevalence of clinical and subclinical mastitis $12.5 \%$ and $25 \%$ respectively as in Table (1), which were lower than that found by Bourabah et al.., (2013) and Mahlangu et al,., (2018) who recorded high prevalence of subclinical mastitis in goats reached $50.9 \%$ by using CMT, out of which $86.5 \%$ yielded bacteria on culture. A positive correlation between CMT and bacteriological pathogens was found in CMT-positive milk samples, where the negative bacteriological samples reported $10 \%$ and $20 \%$ of 


\section{Ultrasonography, Histopathological, Udder Alterations ......}

subclinical and clinical samples respectively, as in Table (2). The CMT is a more perfect, efficient, and reliable screening tool for diagnosis of subclinical mastitis in the dairy goat. Some authors have recorded very high sensitivity and specificity of CMT as a screen test (Mbindyo and Bebora, 2014; Mahlangu et al.., 2018 and Danmallam and Pimenov 2019). The bacteriological examination resulted in Coagulasenegative Staphylococci were the most common isolates $(30 \%, 40 \%)$, followed by $S$. aureus $(25 \%, 30 \%)$ and Streptococcus spp. $(25 \%, 30 \%)$, then E. coli $(10 \%, 0 \%)$ in harmony with the results that were recorded by Bourabah et al., (2013) and Gabli et al., (2019). Thus, milk is considered an excellent media for pathogen growth affected by many factors as the unhygienic condition of the farm, improper management, poor hygiene, teat injuries as predisposing factors for mastitis.

Most bacteria in the current study were sensitive to Cefquinome, Amoxicillin + clavulanic acid, Norfloxacin, Gentamycin and Cephradine, at the contrast increasing bacterial resistant pattern to Penicillin G and Tetracycline sited in Table (3). These are probably due to a long time and extensively used of these antibiotcs in the treatment of mastitis, as reported by Priya and Ayodha (2016); Ebtsam et al., (2018) and Danmallam and Pimenov (2019).

Ultrasonography of the udder is a non-invasive technique which is easily performed. By using appropriate equipment, the teat, teat canal, gland cisterns and udder parenchyma can be visualized and evaluated. The parenchyma of a healthy mammary gland appeared as a homogenous structure of average echogenicity filled with anechoic content (milk) as in Fig. (2). However, the characteristic changes that occur during all different mastitis phases in the mammary glandular parenchyma, teat and the milk appeared with different echoicity as in Fig. (3-5). These findings are in agreement with results of Ebtsam et al. (2014a); Fasulkov et al., (2014); Santos et al. (2014) and Adam et al. (2017). Therefore, the using of ultrasonography can help to differentiate possible changes causes, prognosis and monitoring response to therapy (Fasulkov et al., 2013 and Fasulkov et al.., 2015)

Despite little information about mammary gland biopsy in goats for the diagnosis of mammary disorders, some previous studies had considered it to be a tool to study the cellular proliferation and diversity that occur during mastitis and help elucidate these processes or possible complications (Guilherme et al...,2018). Tissue samples obtained by surgical biopsy technique for histopathological features revealed different characteristic features of chronic, diffused interstitial mastitis lesions compatible with a longstanding subclinical infection, especially designated by the numerous corpora amylacea, leukocyte infiltrates and interstitial fibrosis scattered throughout the mammary tissue, that indicated severe tissue damage induced by a bacterial infection. Mastitis effect was more severe at the alveolar lumen than in the ducts, as seen in Fig. (7-10). These pathological alterations were coming in accordance with Hussain $\boldsymbol{e t}$ al., (2012); Abba et al., (2014) and Ibrahim et al., (2016) who noted similar changes in mammary glands of naturally and experimental mastitis infected ruminants.

The existence of cystic dilatation of lactiferous ducts, compact and dense muscular fibers along the teat duct, coupled with the increased number of relatively large vessels at teat end with hyperplastic down growth of basal layer with melanosis and hyperkeratosis appeared to increase resistance to teat injuries, as observed in this study at Fig. (11 and 12) and in agreement with El-Sayed et al. (2009); Hanaa et al.,(2016). These results designated pathological changes taking place in udder tissue and could be due to severe tissue damage due to different mastitis pathogens affection.

\section{CONCLUSION}

It can be concluded that, mastitis is an imperative disease of goats. That could lead to impairment of udder function or animal loss with a public health hazard. Prevention is as important as treatment. Frequently monitoring and periodical examination for detection of mastitis are recommended for all dairy herds. All forms of mastitis require microbiological confirmation for final diagnosis. Proper environmental and hygienic measurements are crucial for control and minimize the impact of it. Ultrasonography and histopathology give a clear prognosis for the status of the udder and teat helping in the decision of culling and replacement or treatment of infected animals, that making veterinarians easy to work and follow up the performance.

\section{REFERENCES}

ABBA, Y.; ADAMU, L.; IGBOKWE, I.O.; HASSAN, S.U. AND SULE, D., 2014. Effect of clinical mastitis on the gross morphometry and histopathology of mammary glands of Sahel goats. Int. J. Livestock Res., 4, 1; 99-106

ABU, A. H., MHOMGA, L.I. AND AKOGWU, E. I. 2013. Assessment of udder characteristics of West African Dwarf (WAD) goat reared under different management systems in Makurdi, Benue State, Nigeria. African Journal of Agricultural Research, vol. 8, n. 25, p. $3255-3258$. 
ADAM, Z. E. A. S., RAGAB, G. A. N., AWAAD, A. S., TAWFIEK, M. G. AND MAKSOUD, M. K. M. A 2017. Gross anatomy and ultrasonography of the udder in goat J. Morphol. Sci., vol. 34, no. 3, p. 137-142

ADDIS MARIA FILIPPA, TIZIANA CUBEDDU, YLENIA PILICCHI, STEFANO ROCCA AND RENATA 2019. Chronic intramammary infection by Listeria monocytogenes in a clinically healthy goat - a case report. BMC Veterinary Research, 15:229

AHMED Y. F, OMIMA H. EZZO AND SAWSAN M. AHMED 2020. Some Udder Problems Associated with Productivity in Goats Egypt. J. Vet. Sci. Vol. 51, No.1, pp. 1-9

BANCROFT, J.D. AND GAMBLE, M. 2018. Theory and Practice of Histological Techniques. 8th Ed, Churchill Livingstone London, UK, and pp: 125-138 \&328-329.

BOURABAH, A., A. AYAD, L. BOUKRAA, S. M. HAMMOUDI, AND H. BENBAREK, 2013. "Prevalence and aetiology of subclinical mastitis in goats of the Tiaret Region, Algeria, "Global Veterinaria, vol.11, no.5,pp.604-608,

CLINICAL AND LABORATORY STANDARDS INSTITUTE in 2014. Performance standards for antimicrobial susceptibility testing; Twenty-Fourth Informational Supplement. Wayne, PA: Clinical and Laboratory Standards Institute. CLSI document; M100S24

DANMALLAM FA AND PIMENOV NV 2019. Study on prevalence, clinical presentation, and associated bacterial pathogens of goat mastitis in Bauchi, Plateau, and Edo states, Nigeria, Veterinary World, 12(5): 638.

EBTSAM E. Z. KOTB AND JEHAN A. GAFER, 2020. Molecular Detection Of Toxins And Disinfectant Resistance Genes Among Staphylococcus aureus Isolated From Dairy Cattle In Egypt. Journal of Applied Veterinary Sciences, 5 (1): 35-45

EBTSAM E. Z. KOTB, EL-SHAFAIE M.A. AND SAMEH A. IBRAHEM 2018. Molecular characterization of toxigenic and antibiotic-resistant of S.aureus of recurrent bovine mastitis. Assuit Vet. Med. J. Vol.64 No.158, pp. 1-8

EBTSAM E.Z. KOTB, ASHRAF M. ABU-SEIDA AND MOSTAFA S. FADEL 2014a. The Correlation Between Ultrasonographic and Laboratory Findings of Mastitis in Buffaloes (Bubalus Bubalis). Global Veterinaria 13 (1): 68-74

EBTSAM E. Z. KOTB, RAGHIB R. W. AND OLA A. ABDEL FATTAH 2014b. The economic impact of mastitis in some dairy farms in Egypt. J. Egypt Vet. Med. Assoc. 74,no 4, 579-595

EBTSAM E.Z. KOTB 2008. Some studies on the immune response of lactating bovine mammary gland to different mastitic vaccines. Thesis of $\mathrm{Ph}$ degree in Vet. Med. Sc. Cairo university

EBTSAM E.Z. KOTB 2001. Detection of bacterial antigens in milk $\mathrm{s}$ from clinical cases of bovine mastitis. Thesis of master degree in Vet. Med. Sc. Cairo University

EL-SAYED, E.H.; EL-SHAFIE, M.H.; SAIFELNASR, E.O.H.; ABU EL-ELLA, A.A. 2009. Histological and histochemical study on mammary gland of Damascus goats through stages of lactation. Small Ruminant Research, 85;11-17.
EL-SAYED, E.H.; HASSAN, L.R.; SAIFELNASR, E.O.H.; ASHMAWY, T.A.M. 2013. Ultra-structure study of the mammary gland in Zaraibi goats during different stages of lactation. Egypt J Sheep Goat Sci., 8;33-45.

FASULKOV IVAN, MANOL KARADAEVA, NASKO VASILEVA, RADOSTIN SIMEONOVB, VALENTINA URUMOVAC, AND ELEONORA MLADENOVA 2015: Ultrasound and histopathological investigations of experimentally induced Staphylococcus aureus mastitis in goats. Small Ruminant Research $129 ; 114-120$.

FASULKOV M.; KARADAEV AND M. DJABIROVA 2014. Ultrasound measurements of teat structures in goats. Revue Méd. Vét., 165, 5-6, 188-192

FASULKOV, IR., YOTOV, S., ATANASOV, A. AND ANTONOV, AL. 2013. Evaluation of different techniques of teat ultrasonography in goats. Journal of the Faculty of Veterinary Medicine, Istanbul University, , vol. 39, n. 1, p. 33-39

FASUlKOV, IR., GEORGIEV, PI., ANTONOV, AL. AND ATANASOV, AS 2010. B-mode ultrasonography of mammary glands in goats during the lactation period. Bulgarian Journal of Veterinary Medicine, vol. 13, p. 245-251.

GABLI Z., DJERROU Z., GABLI A.E. AND BENSALEM M. 2019. Prevalence of mastitis in dairy goat farms in Eastern Algeria, Veterinary World, 12 (10): $1563-1572$

GUILHERME PUGLIESI, GABRIELA DALMASO DE MELO, GILMER ARANTES ATAÍDE JR, CARLOS AUGUSTO GONTIJO PELLEGRINO, JÚLIO BARBOZA SILVA, CECÍLIA CONSTANTINO ROCHA, IGOR GARCIA MOTTA, JOSÉ LUIZ MORAES VASCONCELOS, MARIO BINELLI 2018. Use of Doppler ultrasonography in embryo transfer programs: feasibility and field results. Proceedings of the 32nd Annual Meeting of the Brazilian Embryo Technology Society (SBTE); Florianopólis, SC, Brazil, August 16th to 18 th

HANAA ASFOUR, A.E.; ABEER ANWER, M.; NABEEH, A.M. AND ABEER EL-METWALLY, E. 2016. Some studies on Pasteurella multocida as a causative agent of mastitis in dairy cows and ewes. Assiut Vet. Med. J., 62, 150; 143-156.

HUSSAIN, R.; KHAN, A.; JAVED, M.T. AND RIZVI, F. 2012. Possible risk factors associated with mastitis in indigenous cattle in Punjab, Pakistan. Pak Vet J, 32, $\underline{\mathbf{4}}$; 605-608.

IBRAHIM, H.H.; JESSE, F.F.A.; ABBA, Y.; CHUNG, E.L.T.; MARZAI, A.D.; HARON, A.W.; ZAMRSAAD, M.; OMAR, A.R. AND SAHAREE, A.A. .2016: Clinical and histopathological study on reproductive lesions caused by Pasteurella multocida type B2 immunogens in buffalo heifers. Bulgarian J. Vet. Med.

JAI W, LEE S.N., OBRIEN A., JUIDRY J., MAX K.A. AND SHAFAR W.A. 2005. Effect of the trivalent vaccine against $S t a p h$. aureus mastitis lymphocytes subpopulation antibody production and neutrophil phagocytosis. Canadian J. Vet. Res., 69: 11-18. 


\section{Ultrasonography, Histopathological, Udder Alterations}

MAHLANGU PRECIOUS, NAOMI MAINA AND JOHN KAGIRA 2018. Prevalence, Risk Factors, and Antibiogram of Bacteria Isolated from Milk of Goats with Subclinical Mastitis in Thika East Subcounty, Kenya J. of Vet. Med. Volume 2018, Article ID 3801479, 8 pages

MBINDYO C. M. AND BEBORA L. 2014. A crosssectional on the prevalence of subclinical mastitis and antimicrobial susceptibility patterns of the bacterial isolates in milk samples of smallholder dairy goats in Kenya," American Journal of Research Communication, vol.2,no.8,

NATIONAL MASTITIS COUNCIL (NMC) 2011.3rd. International Symposium on Mastitis and Milk Quality Proceedings; 2011: 38-42

NOGUEIRA FILHO, A., FIGUEIREDO JÚNIOR, C.A. AND YAMAMOTO, A. 2010. Mercado de Carne, Leite e Pele de Caprinos e Ovinos no Nordeste. Série Doc. Etene, Fortaleza, p. 125

PRIYA, S. AND S. AYODHA, 2016. "Bacterial and antibiogram studies of milk samples of clinical mastitis in goats," IOSR Journal of Agriculture and Veterinary Science, vol.9, no.6, pp. 33-35.

QUINN, P.J., MARKEY, B.K., CARTER, M.E., DONELLY, W.J. AND LEONARD, F.C. 2002. The bacterial cause of bovine mastitis. In: Veterinary

How to cite this article:

Ebtsam E.Z. Kotb, Fadel, M., Ola A. Abd ElFattah, Azab, A.M.S. and Amal Z.A. Leil. 2020. Ultrasonography, Histopathological Udder Alterations And Bacteriological Investigations For Diagnosis Of Mastitic Goats. Journal of Applied Veterinary Sciences, 5(2): 77-86.

DOI: $\underline{\text { HTTPS://DX.DOI.ORG/10.21608/JAVS.2020.85593 }}$
Microbiology and Microbial Diseases. Blackwell Science Ltd, a Blackwell Publishing Company, Oxford, UK. p465-75.

SANTOS V.J.C., K.M.M.G. SIMPLÍCIO, D.C.C. SANCHEZ, V.T. ALMEIDA, P.P.M. TEIXEIRA, L.N. COUTINHO, L.F.S. RODRIGUES, M.E.F. OLIVEIRA, M.A.R. FELICIANO AND W.R.R. VICENTE 2014. Conventional and Doppler ultrasonography on a goat with gangrenous mastitis. Arq. Bras. Med. Vet. Zootec., v.66, n.6, p.1931-1935, 2014

SHAHEEN, M.; TANTARY, H.A. AND NABI, S.U. 2016. A Treatise on bovine mastitis: Disease and disease economics, etiological basis, risk factors, impact on human health, therapeutic management, prevention and control strategy. J. Adv. Dairy Res., 4, 1; 10 pages.

SOUSA, F.C.; PAULA, A.R.; CAMPELO, L.S.; MELO. L.M.; FREITAS, V.F. AND TEIXEIRA, D.A. 2017. Mammary biopsy in induced lactating goats: Assessment of post-biopsy milk properties and ultrasonographic appearance. Ciencia Animal Brasileira Goiânia, 18, 1-7.

SZENCZIOVA I. AND STRAPAK P. 2012. Ultrasonography of the udder and teat in cattle, perspective measuring technique. Slovak J. Anim. Sci., 45 (3): 96-104. 